\title{
Social Change in Javanese Societies' Speech Patterns Based on the Cangkriman Local Wisdom on Instagram
}

\author{
KD Wijayanti' ${ }^{1}$ F Kurwidaria ${ }^{2}$, and AA Rahadini ${ }^{3}$ \\ 1,2,3 Teacher Training and Education Faculty of Sebelas Maret University Surakarta, Indonesia \\ ${ }^{3}$ Doctoral Student of Yogyakarta State University, Indonesia \\ kenfitria_dw@staff.uns.ac.id
}

\begin{abstract}
Cangkriman is a kind of puzzle in Javanese. To answer the puzzle, the similarity of presuppositions is needed. The similarity of background knowledge and context can result in the association of speakers and speech partners' similarities. This article discusses social changes in the Javanese speech patterns connected to the cangkriman local wisdom on Instagram. This aims to describe the form and lingual markers of presuppositions in the cangkriman, and describe the values of cangkriman local wisdom on Instagram as one of the popular social media. The research data are in the form of words, phrases, clauses, and sentences that contain characters, and the data collection is in the form of techniques and recordings. The results of the analysis show two types of presuppositions namely single and multiple presuppositions. Meanwhile, values of local wisdom in Javanese cultures can be found in the cangkriman and the use of diction is closely related to the culture and traditional life of the Javanese community in the form of traditional tools, food, ceremonies, animals, behaviors, and attitudes. In its development, cangkriman spoken on Instagram aims not only to entertain, but also to deliver messages that contain local wisdom covertly.
\end{abstract}

Keywords: Social change; speech patterns; cangkriman; local wisdom of Javanese culture; Instagram

\section{INTRODUCTION}

Javanese is a manifestation of people's creativity, taste, and intention based on the values of local wisdom. In daily communication, Javanese people tend to use a pre-code (pralambang). Cangkriman is a form of Javanese culture that uses syndicated structures. It is also a puzzle that requires answers. To answer these puzzles, the similar knowledge and presuppositions background is needed. The relationship between language, culture and mind is reflected in the 
theory of Linguistic Relativity and the Sapir-Whorf's Hypothesis that our perception of reality is influenced by the first language we learn[1]. The perception similarity will facilitate an understanding of meanings. However, in reality the meaning of cangkriman is only expressed within the limits of answering the puzzle. The Cangkriman always shows aspects of traditions closely related to the philosophical meanings associated with the local wisdom. The jurisdiction in Cangkriman is closely related to the culture of Javanese society, namely regarding the results of cultures, behaviors, attitudes, and beliefs. The local wisdom of the ancestral traditions must be preserved to survive the onslaught of the globalization era. Hence, it is necessary to pay attention to the implementation of local wisdom values of Javanese cultures as reflected in the presuppositions of Cangkriman.

A culture in the Javanese society is famous for its subtle speech code commonly called pralambang. To convey ideas to the speech partner, a speaker should not speak frankly, but symbolically. Therefore, moral teachings concerning Javanese life are secrets within expressions. Symbolization is inseparable from lifestyle, social system, religion, and social mobility. Disguised attitudes and behaviors are set to form Javanese society. The local wisdom in the cangkriman serves to describe the culture inherent in the community of its creators.

Cangkriman is a form of Javanese oral culture. As a puzzle, cangkriman requires answers. Cangkriman (puzzle) is a form of language game or word play because humans are playing creatures (homo ludens) and, as a form of language or words, the true character continues to live according to the development of society[2]. Prabowo argues that cangkriman or capeyan commonly called badhekan contains words that must be guessed[3]. Cangkriman has four types, namely: wancahan, pepindhan, tembang, and blenderan. Cangkriman in Javanese cultures is categorized as oral traditions that are transmitted from generation to generation. Therefore, variations and forms can be made possible. However, the development of variations in cangkriman forms will not eliminate the authenticity of the Javanese cultural results.

Presuppositions can be interpreted as a common ground among speakers and speech partners who communicate indirectly. The similarity is that the background knowledge about something under discussion will be related to the speech partner who attempts to understand the speakers' intentions. Pragmatics is the study of invisible meaning, or how we know what is meant even when the meaning is actually not said or written[4]. The meaning of pragmatic speech in a real speech is not always pertinent to utterances that are truly spoken by the speaker[5]. The same assumption holds as a main character, a speaker delivers a message to the speech partner (the interlocutor). The context of speech plays an important role, so that the message intact is interpreted by the opponent considerably. To interpret and answer the puzzles on the framework, it is necessary to have the same presuppositions and understandings of the context between the speakers and the speech partners. Saddhono said that the use of language by speakers is always patterned and influenced by culture as the background of speakers[6].

Instagram is a kind of social media used in daily communication. The younger generation knows Instagram as a means to convey ideas and establish friendship in the cyberspace. The Javanese societies' patterns have developed over time through the discovery of Javanese Instagram accounts that consistently disseminate ideas concerning local cultural wisdom, like @filosofi_jawa, @komikalip, @merawatjogja, etc. In these accounts, the local wisdom of Javanese culture deals with traditional expressions as a means of delivering ideas, one of which uses cangkriman in several posts. The popular cangkriman form is usually used as a means of entertainment and several other purposes. 


\section{METHOD}

The data in this study are in the form of words, phrases, clauses, and sentences that contain values of local wisdom in the cangkriman and the social change in the Javanese societies' speech patterns. The data source is a library on Instagram as a kind of social media. The techniques of collecting data are observing and note-taking, listening to the users of cangkriman in the daily life of Javanese people and recording it using the data card. The matching method is used to analyze the cangkriman data. The use of the equivalent matching method in this study is mainly concerned with the pragmatics and the definitions of speakers and speech partners. In this matching method, basic techniques and advanced techniques are used interchangeably. The basic technique is the determining element (PUP) technique that uses tools in the form of mental breakdown power by the researcher[7]. The advanced technique is in the form of an appeal connection technique (HB) or the tool in a form of mental appeal. The results of the analysis are presented in the form of words and language symbols.

\section{RESULT AND DISCUSSION}

Based on the background above, a cangkriman presupposition analysis on Instagram is described as follows.

Table 1. Cangkriman Data

\begin{tabular}{|c|c|c|}
\hline Type & Meaning & Cangkriman Data \\
\hline Wancahan & $\begin{array}{l}\text { 'Sleepy grandmother stolen her } \\
\text { tobacco' }\end{array}$ & $\begin{array}{c}\text { Nituk lersure: nini ngantuk diseler } \\
\text { susure }\end{array}$ \\
\hline Wancahan & $\begin{array}{l}\text { 'the cows run away from their } \\
\text { plows that are carried away.' }\end{array}$ & $\begin{array}{l}\text { Pindhang kutut: sapi mblandhang } \\
\text { lukune katut, }\end{array}$ \\
\hline Pepindhan & $\begin{array}{l}\text { 'A son is stepping on her mother; } \\
\text { he is caressed as well' }\end{array}$ & Mboke diidak-idak anake dielus-elus, \\
\hline Tembang & $\begin{array}{l}\text { 'Bapak pocung your mouth is } \\
\text { facing up/ Going to the spring/ } \\
\text { Perched on the left side/ Arriving } \\
\text { at the house, the puke spits out } \\
\text { water//' }\end{array}$ & $\begin{array}{l}\text { Bapak pocung cangkemu marep } \\
\text { mandhuwur/ Sabane ing sendhang/ } \\
\text { Pencokane lambung kering/ Prapteng } \\
\text { wisma si pocung mutah kuwayal/ }\end{array}$ \\
\hline Balnderan & $\begin{array}{l}\text { 'an elephant step on eggs, but they } \\
\text { are not broken' }\end{array}$ & Gajah ngidak endhog ora pecah \\
\hline
\end{tabular}

(1) Nituk lersure: nini ngantuk diseler susure 'nenek ngantuk dicuri tembakaunya'

The data (1) is categorized as cangkriman wancahan taken from the last syllable. The presumption in this cangkriman wancahan emerges when the acronym is extended. Here 'grandmothers' in the Javanese community often do the 'brood' activity by using spices, one of which is tobacco. The association is similar in terms of the interpretation of the word susur needed by the partner, so that the perception will be the same as the will of the speaker, namely a sleepy grandmother whose tobacco is stolen. The cangkriman emphasizes the cultural activities of the Javanese people, especially the women, namely the bride who made various kinds of spices intended for the dental treatment or care. Besides, broiling is also used as a social 
value system or a form of respect for guests. In the engagement ceremony, it is always used as a symbol of the bride and groom's potential bond. The composition consists of a betel that means humble, and lime symbolizes good descendants, tobacco is interpreted as a steadfast heart, and areca nut means a hope of getting good offspring and a successful life.

(2) Pindhang kutut: sapi mblandhang lukune katut, 'the cows run away from their plows that are carried away.'

The cangkriman in data (2) is categorized as a type of wancahan that is formed from the last and second last syllable in each word. The presuppositions that emerge in the dual linkage cangkrima, namely in the form of acronyms and acronyms. The presumption at the time was in the form of an acronym that emphasizes an assumption of the partner's speech on one type of cuisine (pindhang) and animal (kutut). The partner thinks whether or not this type of dish is made of a wart bird. However, the presumption becomes apparent in that the acronym's extension can be learned, namely the sapi mblandhang lukune katut, 'the cows run away from their plows that are carried away'. The Javanese people have carried out agricultural since a long time ago, namely plowing the fields by using a driving force of cattle. Plowing cows are considered beneficial because they not only cultivate the land, but also produce dungs used as organic fertilizers that accidentally fall into the rice fields. Luku for Javanese people has a philosophical meaning that is rooted in values of local cultural wisdom. Ngluku activities are interpreted as the beginning of a phase of life based on the practice of 'ihtiar'. In addition, the farmer's plowing tool or luku is operated manually or it is commonly called pegangan dicekel that means the grip should be held. The philosophy behind this tradition is that you should hold principles in life, so that that determine the steps to take. The small agricultural tool called luku is run by stepping on its part firmly, or it is often called mancad that can be interpreted as a navigation for human life and it must have a strong foundation.

(3) Mboke diidak-idak anake dielus-elus, 'A son is stepping on her mother; he is caressed as well.

The answer to this cangkriman is andha or traditional stairs made of bamboo. The data (3) can be classified into a type of cangkriman pepindhan. The presumption is the act of stepping on the mother (pijakan) and caressing the child (pegangan) to indicate the activity of going up stairs. Javanese people have household tools in the form of andha or 'stairs' which are traditionally made of bamboo, the ladder structure has a footing and handles that are used for going up and down activities. These activities can be interpreted as ups and downs in life. When doing activities using stairs, people show a bowing attitude or humble attitude.

(4) Bapak pocung cangkemu marep mandhuwur/ Sabane ing sendhang/ Pencokane lambung kering/ Prapteng wisma si pocung mutah kuwaya//

'Bapak pocung mulutmu menghadap ke atas/ Perginya ke mata air/ Hinggapnya di pinggang kiri/ Sesampainya di rumah si pocung memuntahkan air//'

'Bapak Pocung your mouth is facing up / Going to the spring / Perched on the left side / Arriving at the house, the puke spits out water/'

The answer to this cangkriman is klenthing or a place of water. The data is categorized as a type of cangkriman song. The song is called the tembang macapat pocung. This song was chosen because it has a short and easy structure to remember. Presuppositions arise after hearing 
or reading the song in a full version, because the lingual marker is set to answer the puzzle in each row. The keywords in each line carry the assumption that a household appliance functions as a temporary water reservoir often called clenthing. The Javanese people in ancient times used klenthing to extract water from springs that were taken home to be drunk or used for household needs. Klenthing for Javanese people has values of local wisdom related to facilities or media that accommodate goodness. In the traditional ceremony of tingkeban or mitoni (seven months of pregnancy), klenthing is symbolized as a condition in which the womb of a pregnant woman contains amniotic fluid. Klenthing is usually used in the luwaran stage whereas the prospective father will run fast towards the klenthing filled with water, then kick it until it breaks. The rupture of the klenthing is like the rupture of membranes in the process of giving birth. This is a symbol of hope for the prospective mother giving birth to a baby.

\section{(5) Gajah ngidak endhog ora pecah 'an elephant step on eggs, but they are not broken'}

The cangkriman's answer is an elephant that did not break. The data (5) is categorized as a type of cangkriman blenderan. The presumption arises when the assumption of a large elephant animal stepping on an egg with a fragile shell must have broken the egg, because this is a type of cangkriman blenderan or word play, so that the partner will think that the opposite is the answer, in this case, the elephant. Javanese people are extremely attached to an elephant and eggs-produced animals. Elephants contain values of local wisdom interpreted as a high power or leaders. Meanwhile, eggs can be interpreted philosophically as the beginning of a life. In an egg is a seed of life, and the egg breaks because of external factors, so that the life ends, and if the egg breaks itself, a life begins.

Cangkriman in Javanese community is often used as a means of entertainment, because it contains aspects of cognitive games that encourage speaking partners to think. In addition, cangkriman can also function as an educational facility for the community, so that they are accustomed to thinking about things based on their insights. The following are the cangkriman images that appear on several Instagram accounts.
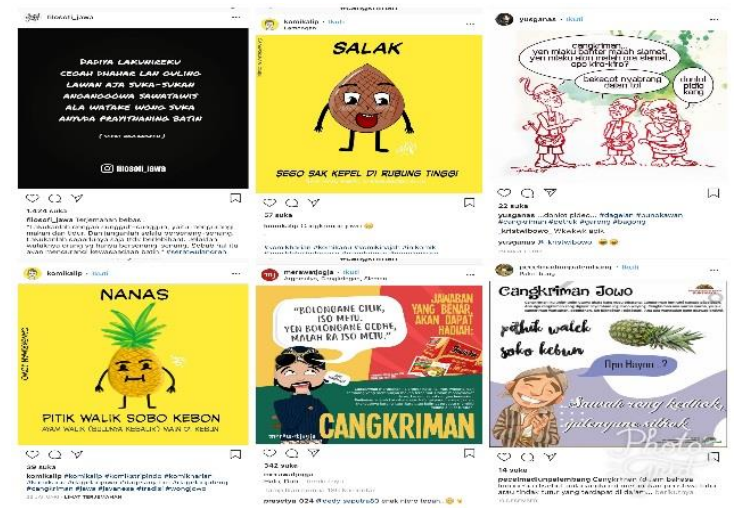

Figure 1. The Use of Cangkriman on Instagram

Instagram is the young generation's media choice as it necessarily remains contemporary. This social media brings forth social changes in the form of Javanese societies' speech patterns. At the beginning, Javanese people tended to use a rambling speech because it was more polite, but on Instagram later on the written caption had a character limit. Therefore, utterances on Instagram are brief but clear, but the message contains traditional expressions based on the presuppositions that speech partners might have. The postings on Instagram elevate the local 
wisdom, and it is a good signal that Javanese culture can attract young generation amid the culture preservation that dynamically happens over time.

\section{CONCLUSION}

The presuppositions that appear in the cangkriman are of two types, single and multiple domains. Multiple presuppositions will only appear in the cangkriman type, while a single presupposition can appear in other types of cangkriman. The local wisdom values of Javanese cultures in the cangkriman are manifested from the use of diction closely related to the culture and traditional life of the Javanese community in the form of traditional tools, traditional food, traditional ceremonies, animals, behaviors, and attitudes. Technological developments enhance social changes that support Javanese societies to use speech patterns replete with a wide variety of local wisdom. This can be seen in the use of cangkriman on several Instagram account posts.

\section{REFERENCES}

[1] S. Ni Wayan, "Menggali Nilai Kearifan Lokal Budaya Jawa Lewat Ungkapan (Bebasan, Saloka, dan Paribasan)," J. Ilm. Bhs. dan Sastra Logat, vol. 5 no 1, 2009.

[2] P. A. Subagyo, "Cara dan Tujuan Penciptaan Cangkriman Wancahan," J. Ilm. Kebud. Sint., vol. 8, no. 2, pp. 69-78, 2014.

[3] P. Dhanu Priyo, Glosarium Istilah Sastra Jawa. Yogyakarta: Narasi, 2007.

[4] G. Yule, Kajian Bahasa. Yogyakarta: Pustaka Pelajar, 2015.

[5] R. Kunjana, Pragmatik Kesantunan Imperatif Bahasa Indonesia. Jakarta: Erlangga, 2005.

[6] K. Saddhono, "Cultural and social change of foreign students in Indonesia: The influence of Javanese Culture in Teaching Indonesian to Speakers of Other Languages (TISOL)," IOP Conf. Ser. Earth Environ. Sci., vol. 126, pp. 1-8, Mar. 2018.

[7] Sudaryanto, Metode dan Teknik Analisis Bahasa. Yogyakarta: Sanatadharma University Press, 2015. 